\title{
Current Aspects of Antibiotic Prophylaxis for Upper Gastrointestinal Bleeding in Cirrhosis Patients
}

\author{
Delvone Almeida and Raymundo Paraná
}

CPgM- Federal University of Bahia, Salvador, BA, Brazil

\begin{abstract}
Bacterial infection is a common complication in cirrhotic patients. The portal hypertension as well as the immune depression observed in these patients can explain this high incidence of bacterial infection. Because of the high probability of cirrhotic patients to develop infections, antibiotic prophylaxis is warranted in some conditions, such as upper gastrointestinal bleeding or after spontaneous bacterial peritonitis. Nevertheless, antibiotic prophylaxis is not widely recommended for cirrhotic patients.
\end{abstract}

Key Words: Antibiotic prophylaxis, cirrhotics, bacterial infections.

Bacterial infections are serious complications found in cirrhotic patients, especially those with upper gastrointestinal bleeding (UGB). Pawels et al. observed that bacterial infections and septic shock are responsible for 39\% of the deaths in these patients [1].

Among the bacterial infections that commonly affect cirrhotic patients after gastrointestinal bleeding, spontaneous bacterial peritonitis (SBP) stands out. In these patients the incidence of bacterial infections reaches $20-50 \%$, while the incidence of SBP varies from 7 to $20 \%$ [2-4].

Furthermore, if we only consider patients with ascites and gastrointestinal haemorrhage, the incidence of SBP is still higher, varying from 30 to $50 \%[5,6]$.

The bacterial infection risk is not the same for all cirrhotic patients with UGB. The risk is higher in patients with advanced disease (Child's B or C) and in patients with repeated bleeding episodes [7-9].

Antibiotic prophylaxis should be particularised for patients at high risk of bacterial infection. Cirrhotic patients with UGB, ascites and low protein

Received on 05 July 2002; revised 24 September 2002.

Address for correspondence: Dr. Raymundo Paraná. Av. Juracy Magalhães Jr. 2096 Sala 510, Salvador-BA 41920.000. Phone: 71.3504651.Fax: 71.3534980.E-mail:unif@svn.com.br

The Brazilian Journal of Infectious Diseases 2002;6(5):266-268 (C) 2002 by The Brazilian Journal of Infectious Diseases and Contexto Publishing. All rights reserved.

$1413-8670$ concentrations are particularly susceptible to the development of serious infectious complications, above all SBP [10]. So these patients should be carefully managed to avoid this complication.

As enteric bacteria cause most SPE episodes, the impact of intestinal flora decontamination on the prevention of this complication was investigated in several studies involving cirrhotic patients with UGB. The objective of this procedure - "selective intestinal decontamination" (SID), is to eliminate or reduce the bacterial load of the intestinal flora [11].

The ideal antibiotic for extended use in SID therapies should be incompletely absorbed by the intestine, be effective against gram-negative bacilli, have reduced action against anaerobic bacteria and have few side effects. SID is also an effective preventive measure for gram-negative bacillus infections in patients with granulocytopenia, indicating the importance of the digestive tract as an infection source in immune depressed patients [12].

The first controlled study, involving 149 UGB patients, was published in 1985. Rimola et al. [13], evaluated intestinal decontamination through the administration of non absorbable oral antibiotics (gentamicin, vancomycin and nystatin or neomycin, colistin and nystatin), initiated upon admission and maintained for 48 hours after the onset of the UGB. The incidence of infections by enteric organisms, particularly bacteremias, SBP and urinary infections, was significantly lower in the group of patients 
that received non absorbable oral antibiotics, compared with controls who did not receive prophylactic antibiotics (34.7\% vs $16.2 \% ; \mathrm{P}<0.025)$; while the incidence of bacterial infection caused by non enteric organisms was similar in the two groups.

Norfloxacin use was considered effective in the prevention of SBP and of other infections caused by enteric organisms in cirrhotic patients with UGB in another study, published in 1992 by Soriano et al. [14]. A 400mg dose, given two times daily, was administered for seven days through a nasogastric tube, immediately after endoscopy, in 119 randomly selected patients, and compared with a control group. The overall bacterial infection incidence was significantly reduced in patients who had taken antibiotics ( $10 \%$ vs $37.2 \% ; \mathrm{P}=0.001)$.

In 1994, Blaise et al. [15] evaluated the effectiveness of $400 \mathrm{mg}$ per day of ofloxacin, initially given IV, followed by oral administration, for 10 days in 91 patients. Amoxacillin and clavulanic acid were also used before each endoscopy. A significant reduction in the bacterial infection rate was observed in the patient group that used the antibiotics $(20 \% \mathrm{vs}$ $66 \% ; \mathrm{P}<0.001)$.

Another prospective study, conducted by Pawels et al. [16] in 1996 with 64 patients, evaluated the prophylaxis of bacterial infections in cirrhotic patients considered at high risk for bacterial infection (cirrhotic Child's $\mathrm{C}$ or patients with bleeding episodes) and concluded that antibiotic prophylaxis (with amoxacillin, clavulanic acid and ciprofloxacin) was effective in preventing bacterial infection, reducing the infection rate (52.9\% vs $18.2 \% ; \mathrm{P}<0.001)$.

Hsieh et al. [17] evaluated 120 patients in 1998, using another quinolone, ciprofloxacin, for seven consecutive days, with a dosage of $500 \mathrm{mg}$, two times per day, administered through nasogastric tubes. There were significant reductions in bacteremia incidence, SBP and urinary infection in the group treated with ciprofloxacin in comparison with the placebo group ( 5 vs $45 \% ; 3.3 \%$ vs $13 \%$ and $5 \%$ vs $18 \%$, respectively). In general, infections were less frequent in the treated group (45\% vs $10 \%$; $\mathrm{P}<0.001)$.

In 1999, Bernard et al. [18] consolidated the five clinical trials cited and published a meta-analysis, including the 534 patients. They concluded that antibiotic prophylaxis significantly increased the average percentage of infection-free patients $(32 \% ; \mathrm{P}<0.001$; CI 95\%: 2.1-12,6), and prevented bacteremia and/or SBP (19\%; P $<0.001 ;$ CI 95\% 11-26), and also significantly increased the average survival rate $(9.1 \%$, CI 95\% 2.9-15.3, $\mathrm{P}=0.004)$.

Sabát et al. [19] analysed the cost-effectiveness ratio of oral antibiotic use for 7 days, accompanied by parenteral antibiotic use for 3 days, for the prophylaxis of bacterial infections in 55 cirrhotic patients, randomly assigned to two groups. They concluded that dual administration was unfavorable, as the cost was significantly higher, without a corresponding decrease in the bacterial infection rate and in internment duration.

Based on these results, we conclude that antibiotic prophylaxis can be useful in preventing infections caused by enteric bacteria, including SBP, in cirrhotic patients with UGB.

On the other hand, there are still no clear indications of a need for antibiotic prophylaxis in cirrhotic patients submitted to invasive procedures involving the digestive tract, whether for diagnostic or for therapeutic purposes [20-22]. Although a distinct trend exists towards antibiotic prophylaxis in patients undergoing digestive endoscopy, especially in those submitted to therapeutic procedures, there still are no studies that support universal use; treatment should be individualised, based on each patient's clinical conditions.

\section{References}

1. Pawels A., Chami N., Guivarch P., et al. Facteurs prédictfs des infections survenant au décours des hémorragies digestives hautes du cirrhotique. Gastroenterol Clin et Biol 1990; 14:219A.

2. Diaz M., Guerrero M., Fernandez C. Infecciones en la cirrosis hepática. Rev Clin Espan 1984;172: 241-50.

3. Navasa M., Fernandez J., Rodes J. Bacterial Infections in Liver Disease. Ital J Gastroenterol Hepatol 1999;31:7 616-25.

4. Andreu M., Sola R., Stiges Serra A., et al. Risk factors for spontaneous bacterial peritonitis in cirrhotic patients with ascites. Gastroenterology 1993;104:1133-8.

5. Blaise M., Pateron D., Trinchet C., et al. Systemic antibiotic therapy prevents bacterial infections in cirrhotics patients with gastrointestinal hemorrhage. Hepatology 1994;20:34-8. 
6. Bleichner G, Boulanger R, Squara P, Sollet P, Parent A. Frequency of infections in cirrhotic patients presenting with acute gastrointestinal haemorrhage. British J Surg 1986;73:724-6.

7. Pawels A., Guivarch P., Debenes B., et al. Analyse des causes et des facteurs de mortalité au décours dés hémorragies digestives hautes du cirrhotique. Gastroenterole Clin et Biol 1991; 15:91A.

8. Caly W., Strauss E. A prospective study of bacterial infections in patients with cirrhosis. J Hepatol 1993; 18:353-8.

9. Toledo C., Flores C., Saénz M., et al. Infecciones Bacterianas en la Cirrosis Hepática. Rev Med Chil 1994;122:788-94.

10. LLach J., Rimola A., Navasa M., et al. Incidence and predictive factors of first episode of spontaneous bacterial peritonitis in cirrhosis with ascites fluid protein concentration. Hepatology 1992;16:724-7.

11. Soriano G., Guarner C., Texido M., et al. Selective intestinal decontamination prevents spontaneous bacterial peritonitis. Gastroenterology 1991;100:477-81.

12. De Vries-Hospers H., Sleijfer D., Mulder N., et al. Bacteriological aspects of selective intestinal decontamination of the digestive tract as a method of infection prevention in granulocytopenic patients. Antimicro Agents Chemothe 1981;19:813-20.

13. Rimola A., Bory F., Teres J., et al. Oral, nonabsorbable antibiotics prevent infection in cirrhotics with gastrointestinal hemorrhage. Hepatology 1985;5:463-7.

14. Soriano G., Guarner C., Tomás A., et al. Norfloxacin prevents bacterial infections in cirrhotics with gastrointestinal hemorrhage. Gastroenterology 1992;103:1267-72.

15. Blaise M., Pateron D., Trinchet J.C., et al. Systemic antibiotic therapy prevents bacterial infections in cirrhotic patients with gastrointestinal hemorrhage. Hepatology 1994;20:34-3.

16. Pawels A., Mostefa-Kara N., Debenes B., et al. Systemic Antibiotic Prophylaxis After Gastrointestinal Hemorrhage in Cirrhotic Patients With a High Risk of Infection. Hepatology 1996;24:802-6.

17. Hsieh W., Lin H., Hwang S., et al. The Effect of Ciprofloxacin in the Prevention of Bacterial Infection in Patients With Cirrhosis After Upper Gastrointestinal Bleeding. Am J Gastroenterol 1998;93:962-6.

18. Bernard B., Grangé J., Khac E., et al. Antibiotic Prophylaxis for the Prevention of Bacterial Infections in Cirrhotic Patients With Gastrointestinal Bleeding: A MetaAnalysis. J Hepatol, 29:1655-61, 1999.

19. Sàbat M, Kolle L, Soriano G, Ortiz J, Pamplona J et al. Parenteral Antibiotic Prophylaxis of Bacterial Infections Does Not Improve Cost-Efficacy of Oral Norfloxacin in Cirrhotic Patients With Gastrointestinal Bleeding. Am J Gastroenterol 1998;93:2457-62.
20. O'Connor J., Sondhi S., Mullen K., McCullough A. A continuous quality improvement initiative reduces inappropriate prescribing of prophylactic antibiotics for endoscopic procedures. Am J Gastroenterol 1999;94:2115-21.

21. Rey J., Axon A., Budzynska A., et al. Guidelines of the european society of gastrointestinal endoscopy antibiotic prophylaxis for gastrointestinal endoscopy. European Society of Gastrointestinal endoscopy. Endoscopy 1998;30:318-24.

22. Mani V., Cartwright K., Dooley J., et al. Antibiotic prophylaxis in gastrointestinal endoscopy: a report by a working party for the British society of gastroenterology endoscopy committee. Endoscopy 1997;29:114-9. 